\title{
Phase Transformations during Low Temperature Nitrided Inconel 718 Superalloy
}

\author{
Yan JING, ${ }^{1,2)}$ Wang JUN, ${ }^{1{ }^{1} *} \mathrm{Gu} \mathrm{TAN}^{2}{ }^{2)}$ Xiong $\mathrm{JI}^{1)}$ and Fan HONGYUAN ${ }^{11}$ \\ 1) School of Manufacturing Science and Engineering, Sichuan University, Chengdu, 610065 P.R. China. \\ 2) Research Institute of Natural Gas Technology, PetroChina Southwest Oil and Gas Field Company, Chengdou, 610213 P.R. \\ China.
}

(Received on December 22, 2015; accepted on February 22, 2016)

\begin{abstract}
The effects of the salt bath nitriding parameters on the microstructure, microhardness and corrosion behavior of Inconel 718 superalloy at temperature ranging from $425-500^{\circ} \mathrm{C}$ were investigated by $X$-Ray diffraction (XRD), scanning electron microscopy (SEM), transmission electron microscopy (TEM) and corrosion test. Experimental results indicated that the microstructure and phase constituents of the surface nitridization are highly process dependent. When Inconel 718 superalloy was subjected to salt bath nitriding, the predominant phases of the nitrided layer were identified as expanded austenite (S phase), austenite and $\mathrm{CrN}$. The thickness of the nitrided layer increased with the time of nitridization. Meanwhile, salt bath nitriding improved the surface hardness dramastically. The maximum value of hardness measured from the treated surface was $2100 \mathrm{HV}_{0.1}$ after $16 \mathrm{~h}$ at $500^{\circ} \mathrm{C}$, which is about 5 times as hard as the untreated material $\left(420 \mathrm{HV}_{0.05}\right)$. Proper low temperature nitriding can improve the erosion corrosion resistance. The sample that was nitrided for $4 \mathrm{~h}$ at $475^{\circ} \mathrm{C}$ had the best corrosion resistance.
\end{abstract}

KEY WORDS: Inconel 718 superalloy; corrosion; salt bath nitriding; microhardness; microstructure.

\section{Introduction}

Due to its good plastic, fatigue and corrosion properties, precipitation hardening IN 718 (Inconel 718) alloy, which is the nickel-iron based superalloy, is commonly applied in chemical and nuclear industries. ${ }^{1,2}$ However,the application of IN 718 is restricted due to its poor tribological performance. This problem can be solved by the development of advanced surface engineering technologies. ${ }^{3,4)}$

Surface hardening of alloys has been investigated since the past half century. Most of the research was focused on plasma nitridization, gas nitridization, plasma carburization and gas carburization of different alloys. ${ }^{5-19)}$ However, much less attention have been paid to nitridization of nickel based superalloys, in that such alloys are difficult to be nitrided..$^{20,21)}$ This is due to the formation of passivated oxide layer on the surface, which impedes the infusion of alloying elements. ${ }^{22)}$ Moreover, the salt bath nitriding was a highly effective and low-cost method with many advantages such as low nitriding temperature, short treatment time, high degrees of shape and dimension stabilities, and easy reproducibility. ${ }^{19-23)}$ However, the liquid phase nitriding was considered harmful to the environment by lots of researchers. The truth is that the main components of the conventional liquid phases for nitriding comprise urea, carbonate, chloride and some nontoxic trace components. ${ }^{24)}$ So if the $\mathrm{NH}_{3}$ gas and the waste slag are controlled properly, liquid

\footnotetext{
* Corresponding author: E-mail: srwangjun@scu.edu.cn DOI: http://dx.doi.org/10.2355/isijinternational.ISIJINT-2015-697
}

nitriding is a environment friendly technology. ${ }^{19)}$

For the corrosion resistant alloy, the conventional nitriding cannot be used because it is well established that nitriding of alloys containing $\mathrm{Cr}$ above $500^{\circ} \mathrm{C}$ produces undesirable $\mathrm{CrN}$ that degrades the corrosion resistance. ${ }^{16)}$ Thus the treatment temperature must be lower. Unfortunately, with the high melting points of main components of salt bath nitriding, the development of low temperature salt bath nitriding is not easy to achieve. Recently, we report that low temperature salt bath nitriding can greatly improve the hardness of stainless steel without impairing the corrosion resistance. ${ }^{24,25)}$ The effects of nitridization temperature and time on the microstructure and corrosion behavior of Inconel 718 alloy remains unknown. This paper, therefore, aims to investigate the influences of the nitriding parameters on surface microstructure and corrosion resistance of IN 718 alloy by using corrosion testings, XRD (X-ray diffractometry), SEM (scanning electron microscopy) equipped with XEDS (X-ray energy dispersive spectrometry) and TEM (transmission electron microscopy).

\section{Experimental Method}

The samples were prepared from grade IN 718 superalloy with the composition shown in Table 1. The surface of each sample was polished to mirror like and then ultrasonically cleaned. The samples were dipped into molten salt at $425-500^{\circ} \mathrm{C}$ for various hours and then cooled in warm water to room temperature. The nitrocarburizing medium for IN 718 alloy was mainly composed of the nontoxic $\mathrm{M}_{2} \mathrm{CO}_{3}$ 
( $\mathrm{M}$ denotes some elements of halogen, such as $\mathrm{K}, \mathrm{Na}$, etc), $\mathrm{CO}\left(\mathrm{NH}_{2}\right)_{2}$ and other trace components. The further information about nitrocarburizing medium can be find in refs. ${ }^{25,26)}$ The $\mathrm{CNO}^{-}$concentration in the salt was above $40 \%{ }^{26)}$

The structural change in the nitrided layer was investigated by optical microscopy and Hitachi S4800 scanning electron microscopy with the Philips EDS tester. The Dmax1400 X-ray diffractometer with $\mathrm{Cu} \mathrm{K} \alpha$ radiation and a nickel filter was used to determine the phases present in the nitrided layer. Cross sections of the nitrided specimens were prepared by twin-jet electropolishing for TEM study, which is performed using a JEOL-JEM 2010 with the accelerating voltage of $200 \mathrm{kV}$.

Corrosion tests were carried out by means of a selfdesigned corrosion device in the laboratory. Detailed information is shown in Fig. 1. Before the corrosion tests, untreated and nitridized samples were surface polished and cleaned by alcohol. Moreover, the surface areas and the initial weights were measured, then the samples were immersed into a 3.5 wt. $\% \mathrm{NaCl}+5$ vol. $\% \mathrm{H}_{2} \mathrm{SO}_{4}+100$ $\mathrm{g} / \mathrm{L} \mathrm{Al}_{2} \mathrm{O}_{3}$ solution spun at $500 \mathrm{r} / \mathrm{min}$ at about $20^{\circ} \mathrm{C}$ for 24 h. The abrasive particles, which produce a very severe erosion conditions, applied in this work were angular white fused alumina $\left(\alpha-\mathrm{Al}_{2} \mathrm{O}_{3}\right)$ particles with the diameter around 100-150 $\mu \mathrm{m}$ and with high hardness (2 500-3 $000 \mathrm{HV}){ }^{27)}$ The impact angle was kept at $90^{\circ}$ to get the maximum slurry rate. The weight of the sample was measured by the precision electron balance with the model of BSA124S (Beijing Sarturius Co., Ltd., China) to an accuracy of $0.1 \mathrm{mg}$. The microhardness was measured using a Micro Hardness Tester

Table 1. Chemical composition of Inconel 718 superalloy (mass\%).

\begin{tabular}{cccccccccc}
\hline elements & $\mathrm{Fe}$ & $\mathrm{Cr}$ & $\mathrm{Mo}$ & $\mathrm{Nb}$ & $\mathrm{Al}$ & $\mathrm{Co}$ & $\mathrm{Si}$ & $\mathrm{Ti}$ & $\mathrm{Ni}$ \\
\hline$\%$ & 18.0 & 18.5 & 3.0 & 5.1 & 0.5 & 0.3 & 0.15 & 1.0 & Bal. \\
\hline
\end{tabular}

with the model of MC010-HVST-1000ZA.

\section{Results and Discussion}

\subsection{Metallography and Nitriding Kinetics}

It was observed that the typical microstructure produced during salt bath nitriding of IN 718 superalloy changed according to the treatment parameters as shown in Fig. 2. Optical microscopy (OM) observation showed that the featureless bright nitrided layers had different microstructures than the substrates. This bright white appearance would also be indicative of a possible enhancement in corrosion resistance to the harsh etchants (such as Marble's reagent) compared to the substrate. ${ }^{10)}$ The nitrided layers are distinguished from the substrate due to the etching degree being different. After nitriding at $500^{\circ} \mathrm{C} / 8 \mathrm{~h}$, the microstructure of the nitrided layer changed. Many slip lines were observed. This phenomenon was also observed in previous reports ${ }^{1,6}$. After nitriding at $500^{\circ} \mathrm{C} / 16 \mathrm{~h}$, cracks and dark zones were observed.

The thickness of treated layer as a function of salt bath

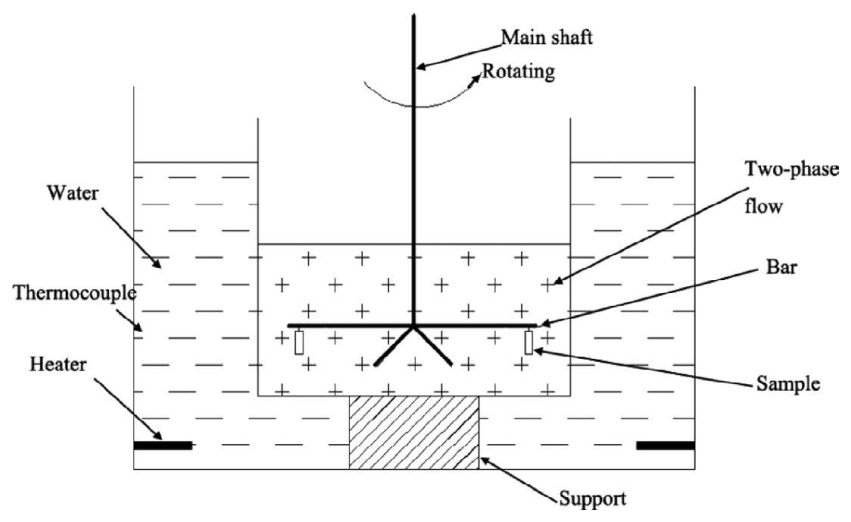

Fig. 1. Schematic diagram of erosion corrosion tester.
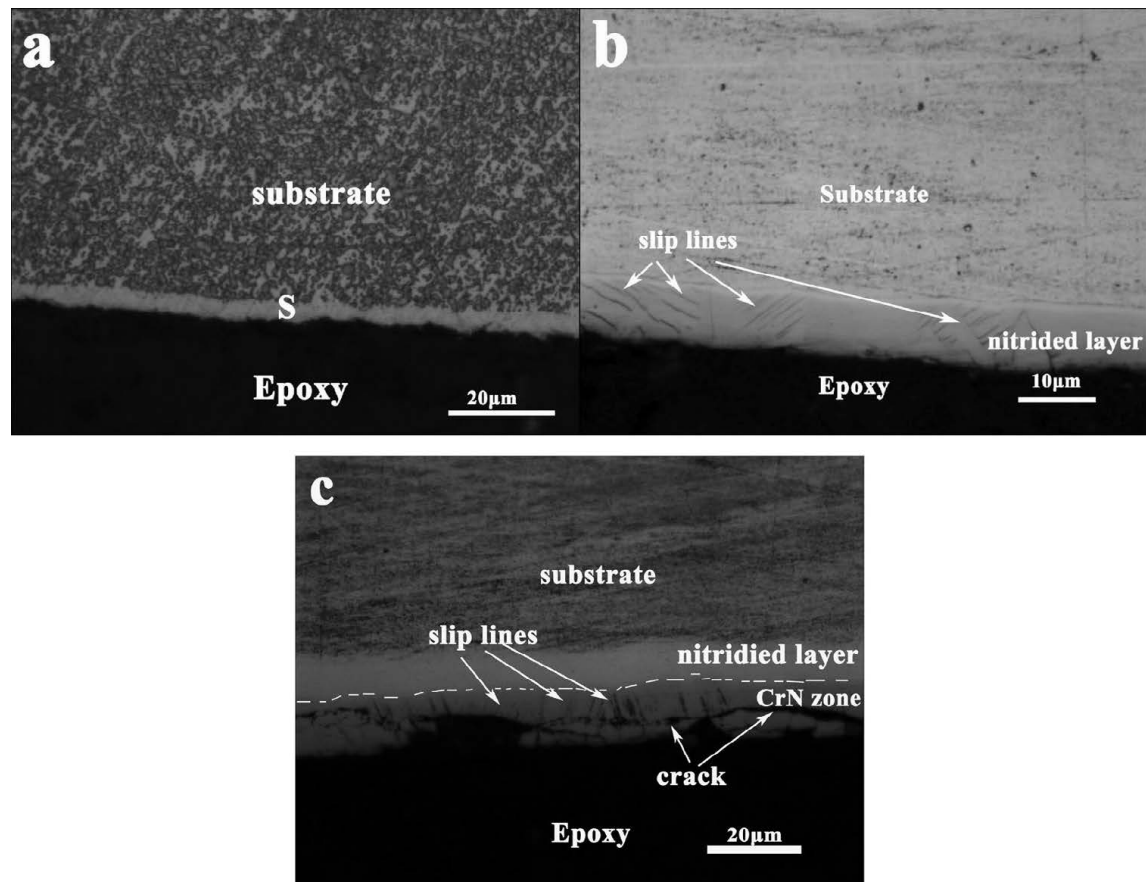

Fig. 2. Optical metallography of Inconel 718 superalloy salt-baths nitrided at $450^{\circ} \mathrm{C} / 4 \mathrm{~h}$ (a), $500^{\circ} \mathrm{C} / 8 \mathrm{~h}$ (b), and $500^{\circ} \mathrm{C} / 16 \mathrm{~h}$ (c). 
nitriding time at different temperature for IN 718 is shown in Fig. 3. It can be seen that thickness increased with the treating time and the thickness of the nitrided layer reached a maximum at $500^{\circ} \mathrm{C} / 16 \mathrm{~h}$.

Figure 4 shows a plot of the square of the thickness of the nitrided layer as a function of nitriding time when temperatures range from $425^{\circ} \mathrm{C}$ to $500^{\circ} \mathrm{C}$. The thickness of the nitrided layer increased with time at any nitriding temperatures as shown in Fig. 4, suggesting a single rate controlling mechanism for the growth of the nitrided layer. ${ }^{8)}$

Based on the diffusion theory of solid state, the thickness of the nitrided layer $(D)$ is related to the nitriding time $(t)$ through a parabolic rate equation as follows: ${ }^{7)}$

$$
D^{2}=2 k_{p} t
$$

where $k_{p}$ is the parabolic rate constant. The parabolic rate constant $k_{p}$ is related to the activation energy $Q$ and preexponential factor $k_{p 0}$ as follows:

$$
k_{p}=k_{p 0} \exp (-Q / R T) .
$$

Within the temperature range of $450-600^{\circ} \mathrm{C}$ the parabolic

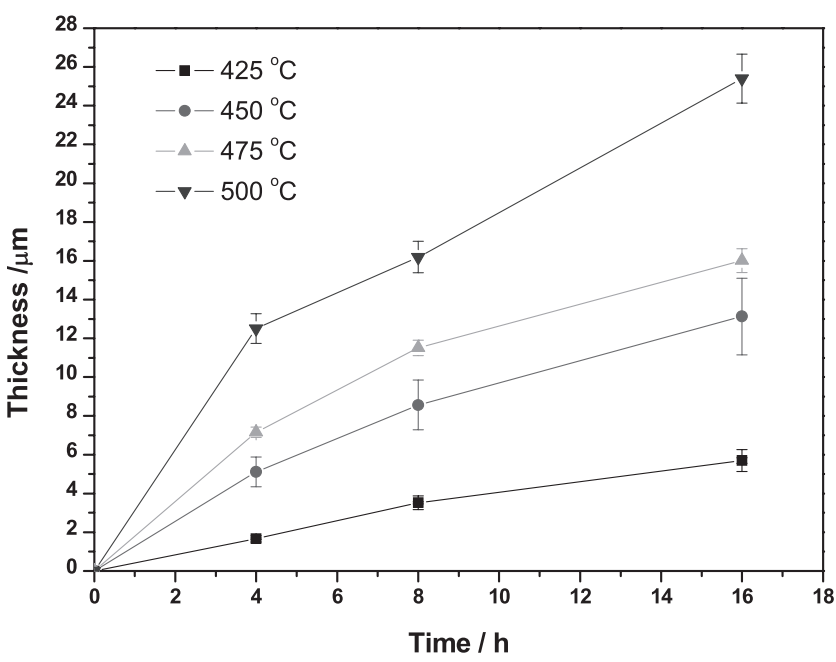

Fig. 3. Thickness of nitrided layer as a function of nitriding time in Inconel 718 superalloy at different temperature.

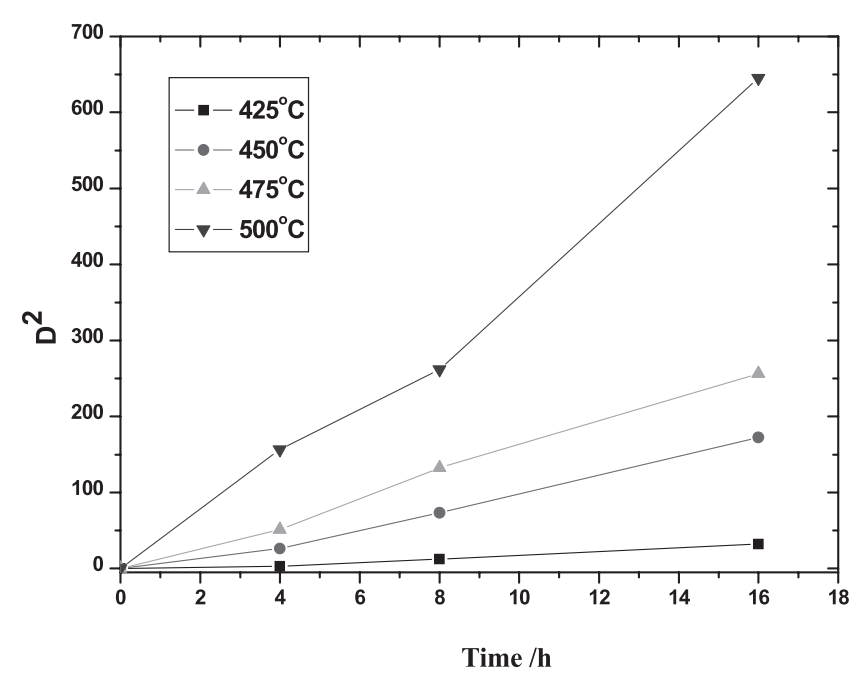

Fig. 4. Plot of square of the thickness of the nitrided layer vs nitriding time with the temperature varied at $425-500^{\circ} \mathrm{C}$. rate constant varied from $10^{-16}$ to $10^{-15} \mathrm{~m}^{2} / \mathrm{s}$. ${ }^{8)}$ Based on (2), a plot of $\ln \left(k_{p}\right)$ was obtained as a function of reciprocal temperature (Fig. 5) from which the activation energy $(Q)$ was deduced as $\sim 166.9 \mathrm{~kJ} / \mathrm{mol}(1.73 \mathrm{eV})$. Table 2 compares $k_{p}$ and $Q$ values obtained in this study with analogous values quoted in literature for other $\mathrm{Ni}-\mathrm{Cr}$ based alloys. The $k_{p}$ and $Q$ values changed with nitriding technology and alloy composition.

\subsection{Phase Analysis of the Nitrided Layer of Inconel 718 Superalloy}

Figures 6-9 show the X-ray diffraction patterns of the untreated IN 718 and IN 718 nitrided at $425-500^{\circ} \mathrm{C}$. The phase composition of nitriding layers on the IN 718 superalloy depends on nitriding parameters and nitrogen potential. As depicted in these figures, it can be clearly seen that austenite $(\gamma-\mathrm{Fe})$ peaks in the non-treated sample are very strong. Detailed information about microstructure of IN 718 superalloy after nitriding could be found in previous reports. ${ }^{5)}$ After nitriding, XRD patterns of the samples changed dramatically for different nitriding temperatures and times, indicating the strong impact of these parameters.

Figure 6 shows different X-ray diffraction patterns of non-treated samples and nitrided IN 718 under different nitriding times at $425^{\circ} \mathrm{C}$. The microstructure of the nitrided

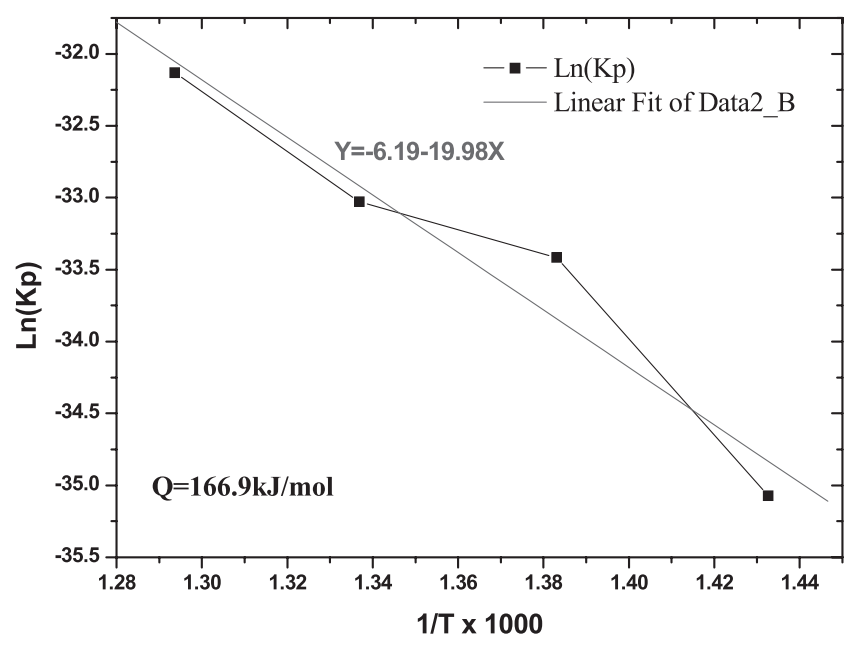

Fig. 5. Arrhenius plot of logarithm of the rate constant vs reciprocal temperature.

Table 2. Parabolic rate constants and activation energies of Inconel superalloys.

\begin{tabular}{ccccc}
\hline Alloy & Temperature $/{ }^{\circ} \mathrm{C}$ & $K_{p}\left(\mathrm{~m}^{2} / \mathrm{s}\right)$ & $Q(\mathrm{~kJ} / \mathrm{mol})$ & Ref \\
\hline 600 & 450 & $1.76 \mathrm{E}-16$ & 62.7 & $8)$ \\
& 500 & $4.06 \mathrm{E}-16$ & & \\
& 550 & $6.61 \mathrm{E}-16$ & & \\
\hline 718 & 425 & $5.86 \mathrm{E}-16$ & 1.73 & This study \\
& 450 & $3.07 \mathrm{E}-15$ & & \\
& 475 & $4.53 \mathrm{E}-15$ & & \\
& 500 & $1.11 \mathrm{E}-14$ & & $13)$ \\
\hline
\end{tabular}




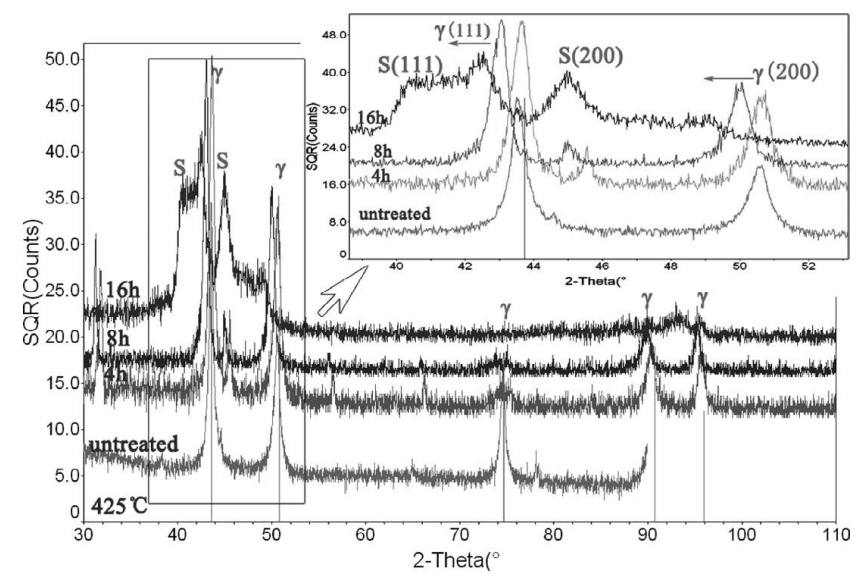

Fig. 6. XRD profile of Inconel 718 superalloy at $425^{\circ} \mathrm{C}$ for various salt-bath nitriding time.

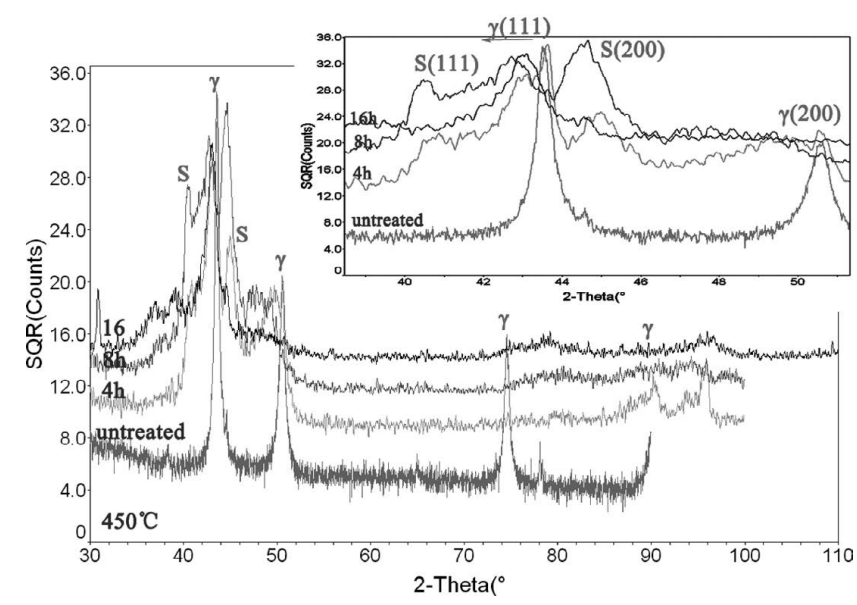

Fig. 7. XRD profile of Inconel 718 superalloy at $450^{\circ} \mathrm{C}$ for various salt-bath nitriding time.

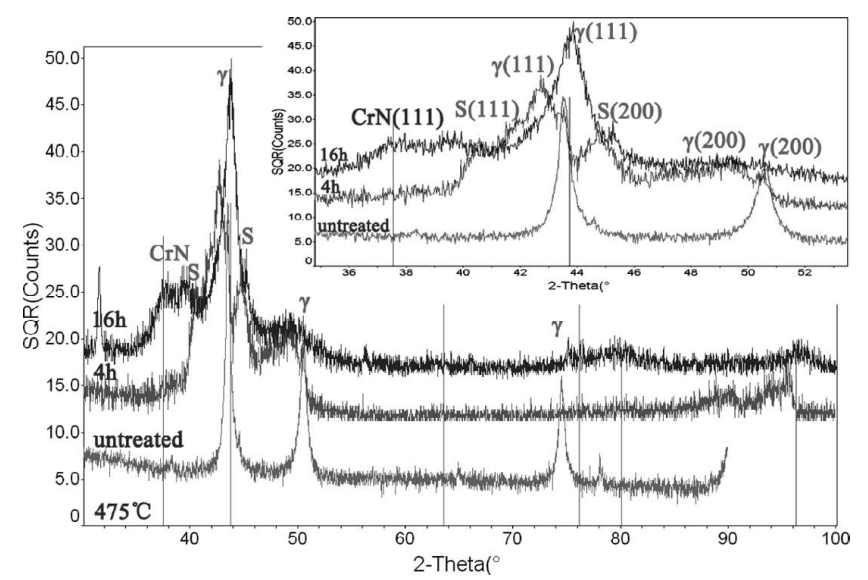

Fig. 8. XRD profile of Inconel 718 superalloy at $475^{\circ} \mathrm{C}$ for various salt-bath nitriding time.

layer depends strongly on the treatment time. After $4 \mathrm{~h}$ and $8 \mathrm{~h}$ nitriding, the microstructure of the layer is similar to the non-treated sample. The peaks of $\gamma_{(111)}$ and $\gamma_{(200)}$ shifted to lower angles, which means that nitrogen atoms diffused into the IN 718 alloy, stayed in the interstitial position and expanded the lattice structure of IN 718. Further increasing

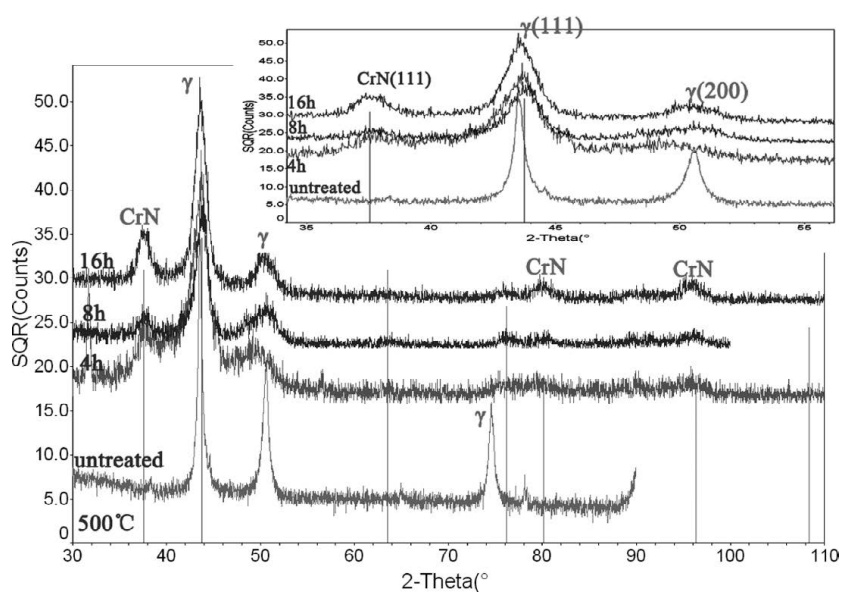

Fig. 9. XRD profile of Inconel 718 superalloy at $500^{\circ} \mathrm{C}$ for various salt-bath nitriding time.

the nitriding time to $16 \mathrm{~h}$ suggests that the $\mathrm{S}_{(200)}$ peak will shift even more to the lower angle. This phenomenon was consistent with Varshni Singh's observation in plasmaassisted IN 718 superalloy nitriding at $450-470^{\circ} \mathrm{C}$. ${ }^{1)}$ It should be noted that the expanded fcc phase was first observed by Ichii, et al. named 'S phase' and later Marchev et al. called it 'm phase'. $\left.{ }^{6}\right)$ With increasing nitriding time, the intensity of austenite peaks are missing. Peaks of $S_{(111)}$ appeared and the intensity of $\gamma_{(200)}$ peaks reduced. Moreover, peak broadening was observed in $16 \mathrm{~h}$ nitriding samples. This broadening is probably due to the gradient of nitrogen, residual stresses, and the defect structure of the nitriding layers. ${ }^{6}$ Therefore, the XRD patterns are characterized by highly overlapped peaks, which were described by Sun and Bell $^{10)}$ as "amorphous-like features". The lattice expansion (showed as peak shifting in the XRD pattern) in different crystallographic directions depends on the stress level and the elastic constant $\left(E_{\mathrm{hkl}}\right)$ of different diffracting planes. ${ }^{28)}$ Considering the anisotropy of $E_{h k l}$ in austenite ${ }^{29)}\left(E_{111}\right.$ is about three times larger than $E_{200}$ ), this is reasonably consistent with the present XRD data in view of the complex stress state caused by the introduction of $\mathrm{N}$ atoms into the $\gamma$ lattice. The $\mathrm{S}_{(111)}$ peaks appear later.

Figure 7 shows different X-ray diffraction patterns of non-treated IN 718 samples and nitrided ones under different nitriding times at $450^{\circ} \mathrm{C}$. After $4 \mathrm{~h}$ and $8 \mathrm{~h}$ nitriding, the nitrided layers have similar microstructures as the samples nitrided at $425^{\circ} \mathrm{C}$. It is also observed that the peaks of $\gamma_{(11)}$ and $\gamma_{(200)}$ shifted to low angles. And the peaks of $\mathrm{S}_{(111)}$ and $\mathrm{S}_{(200)}$ appeared. By increasing the treatment time to $16 \mathrm{~h}$, the expanded austenite peaks intensified. However, only the peak of $\mathrm{S}_{(200)}$ appeared.

Figure 8 shows different X-ray diffraction patterns of non-treated IN 718 samples and nitrided ones under different nitriding times at $475^{\circ} \mathrm{C}$. After $4 \mathrm{~h}$ nitriding, the nitrided layers have similar microstructures as the $450^{\circ} \mathrm{C} / 8 \mathrm{~h}$ treated samples. Similarly, the peaks of $\gamma_{(111)}$ and $\gamma_{(200)}$ shifted to lower angles. And the peaks of $\mathrm{S}_{(111)}$ and $\mathrm{S}_{(200)}$ appeared. With the treatment time increasing to $16 \mathrm{~h}$, the $\mathrm{CrN}$ phase appeared and the peaks of $\mathrm{S}_{(111)}$ and $\mathrm{S}_{(200)}$ disappeared. This is probably due to the precipitation of $\mathrm{CrN}$ depleting chromium in the expanded phase at $475^{\circ} \mathrm{C}$, resulting 
in the formation of a mixture layer of austenite and $\mathrm{CrN}$ (S-phase $\rightarrow \gamma+\mathrm{CrN}$ ).

Figure 9 shows different $\mathrm{X}$-ray diffraction patterns of non-treated IN 718 samples and nitrided ones under different nitriding times at $500^{\circ} \mathrm{C}$. It can be seen that the nitrided layers show both $\mathrm{CrN}$ and austenite. The peaks of $\gamma_{(111)}$ and $\gamma_{(200)}$ did not shift to low angles, and the peaks of $\mathrm{S}_{(111)}$ and $\mathrm{S}_{(200)}$ did not appear. With the treatment time increasing to $16 \mathrm{~h}$, the peaks of $\mathrm{CrN}$ intensified. These results agree with the microscopic observation (Fig. 1(c)). In fact, the nitrogen concentration in sample nitrided at $475^{\circ} \mathrm{C}$ is higher than the equilibrium solubility of nitrogen in the austenitic structure and therefore precipitation of $\mathrm{Cr}$ nitrides occurs. ${ }^{6}$ Moreover, in the case of sample nitriding at $500^{\circ} \mathrm{C}, \mathrm{CrN}$ as well as the austenite is observed in the nitride layer at all time of nitridation. This is because nitrogen can deplete the $\mathrm{Cr}$ in the lattice of IN 718 forming $\mathrm{CrN}$ during the nitriding process at $500^{\circ} \mathrm{C}$. In addition, a relatively stable $\mathrm{CrN}$ nitride is much easier to form at $480^{\circ} \mathrm{C}$ because $\mathrm{Cr}$ nitrides formation is favored due to their high negative enthalpy and low $\mathrm{Cr}$ diffusivity in the matrix at temperatures higher than $450^{\circ} \mathrm{C}$ in austenite stainless steel. ${ }^{15)}$

Table 3 gives the estimated lattice parameters and interplanar spacing from Bragg's law as a function of the nitriding parameters. The lattice parameter expands with increasing nitriding time. This agrees with the results obtained by other studies. ${ }^{1,6,8)}$ The lattice parameter calculated from (200) becomes considerably higher than lattice parameters calculated from (111) planes. This results from the gradual distortion of the cubic symmetry. ${ }^{6}$ ) The $\mathrm{CrN}$ phase precipitated at $475^{\circ} \mathrm{C}$ for long nitriding time or higher nitriding temperature. After the formation of $\mathrm{CrN}$, the $\mathrm{S}$ phase disappeared and the lattice parameter of austenite decreased.

The typical microstructure of the nitrided layer of low temperature salt bath nitriding IN 718 alloy is shown in Fig. 10. According to previous reports, ${ }^{3)}$ there are multiple dislocation clusters caused by nitrogen atom diffusion. Austenite zones have plenty of dislocation (Fig. 10(a)), which is also due to the nitrogen diffusion.

\subsection{Hardness and Erosion Corrosion Behavior}

Figure 11 shows the micro-hardness of nitriding layers as a function of the treatment temperature and time. A sharp increasing of hardness was found near the surface. According to these patterns, the microstructure of the nitrided layer was intensively dependent on the treatment time. After nitriding at $425^{\circ} \mathrm{C}$, the micro hardness increased

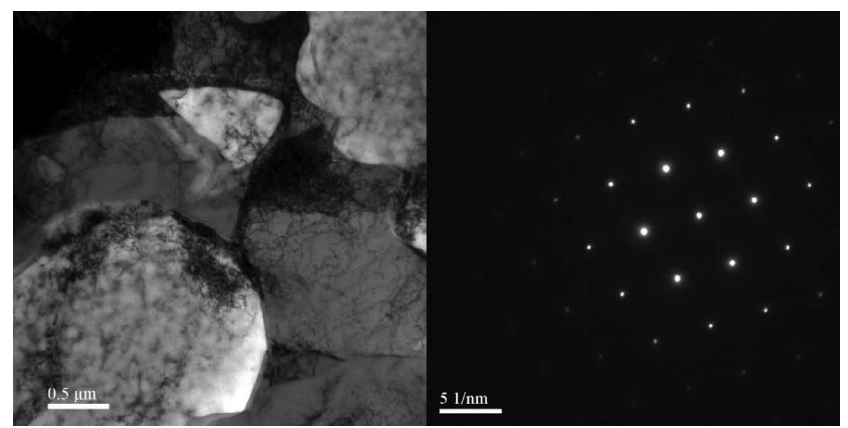

Fig. 10. Microstructure of Inconel 718 alloy salt bath nitrided for 16 hours at $475^{\circ} \mathrm{C}$.

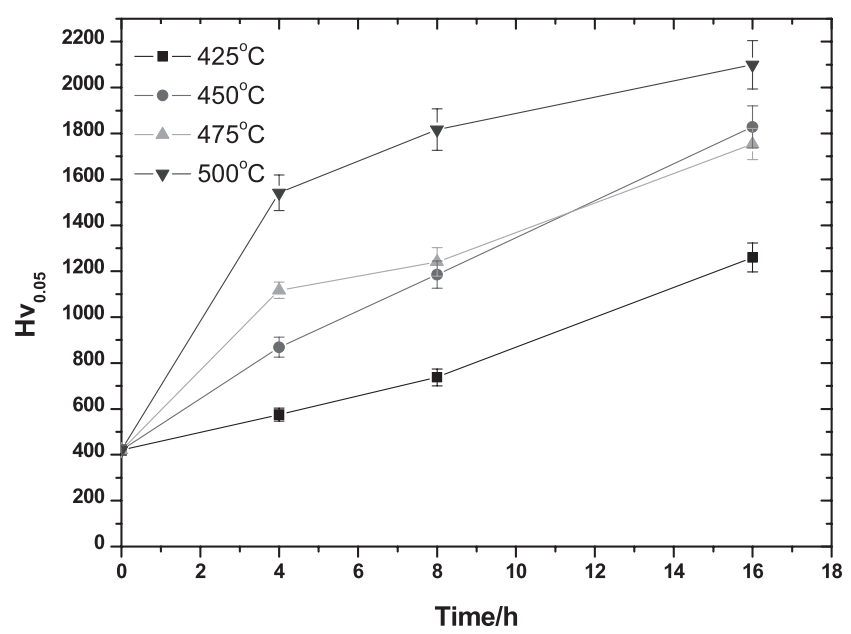

Fig. 11. Micro-hardness of Inconel 718 superalloy nitrided under various temperature and time.

Table 3. Lattice parameters and lattice spacing calculated from (111) and (200) planes for different nitriding time (nm).

\begin{tabular}{cccccccc}
\hline & $\gamma_{(111)}$ & $\Delta \gamma_{(111)}$ & $\gamma_{(200)}$ & $\Delta \gamma_{(200)}$ & $\mathrm{S}_{(111)}$ & $\mathrm{S}_{(200)}$ & $\mathrm{CrN}$ \\
\hline untreated & 3.553 & $/$ & 3.553 & $/$ & $/$ & $/$ & $/$ \\
$425^{\circ} \mathrm{C} / 4 \mathrm{~h}$ & 3.587943 & 0.009835 & 3.5982 & 0.012722 & $/$ & 3.979 & $/$ \\
$425^{\circ} \mathrm{C} / 8 \mathrm{~h}$ & 3.635401 & 0.023192 & 3.6412 & 0.024824 & $/$ & 4.0258 & $/$ \\
$425^{\circ} \mathrm{C} / 16 \mathrm{~h}$ & 3.677837 & 0.035136 & 3.7066 & 0.043231 & 3.831123 & 4.0284 & $/$ \\
$450^{\circ} \mathrm{C} / 4 \mathrm{~h}$ & 3.590888 & 0.010664 & 3.6518 & 0.027807 & 3.827659 & 4.024 & $/$ \\
$450^{\circ} \mathrm{C} / 8 \mathrm{~h}$ & 3.663114 & 0.030992 & 3.8296 & 0.07785 & 3.851388 & 4.053 & $/$ \\
$450^{\circ} \mathrm{C} / 16 \mathrm{~h}$ & 3.616522 & 0.017878 & 3.8024 & 0.070194 & $/$ & 4.2042 & $/$ \\
$475^{\circ} \mathrm{C} / 4 \mathrm{~h}$ & 3.662941 & 0.030943 & 3.6716 & 0.03338 & 3.84931 & 4.0292 & $/$ \\
$475^{\circ} \mathrm{C} / 16 \mathrm{~h}$ & 3.572355 & 0.005447 & 3.7682 & 0.060569 & 3.952194 & 3.9972 & strong \\
$500^{\circ} \mathrm{C} / 4 \mathrm{~h}$ & 3.586211 & 0.009347 & 3.7022 & 0.041993 & $/$ & $/$ & strong \\
$500^{\circ} \mathrm{C} / 8 \mathrm{~h}$ & 3.584652 & 0.008909 & 3.6058 & 0.014861 & $/$ & $/$ & strong \\
$500^{\circ} \mathrm{C} / 16 \mathrm{~h}$ & 3.592447 & 0.011102 & 3.6326 & 0.022404 & $/$ & $/$ & strong \\
\hline * symbi”’ & & & & & &
\end{tabular}


slowly. With increasing treatment temperature, the hardness changes rapidly. The maximum value of hardness measured from the nitrided surface is about $2100 \mathrm{HV}_{0.05}$ for $16 \mathrm{~h}$ at $500^{\circ} \mathrm{C}$, which is about 5 times harder the non-treated material $\left(420 \mathrm{HV}_{0.05}\right)$. The extremely high values of the microhardness can be explained by the induced stress fields, which originate from the many dislocation clusters and stacking faults generated by the supersaturation of nitrogen in solid solution. ${ }^{6,711)}$ And for the $16 \mathrm{~h}$ and $40 \mathrm{~h}$ nitrided samples, the dramatic increasing of hardness is probably due to the formation of $\mathrm{Fe}$ and $\mathrm{Cr}$ nitrides. ${ }^{15}$ )

The erosion corrosion rates of the non-treated and different nitriding times samples etched by 3.5 wt. $\% \mathrm{NaCl}$ $+100 \mathrm{~g} / \mathrm{L} \mathrm{Al}_{2} \mathrm{O}_{3}+5$ vol. $\% \mathrm{H}_{2} \mathrm{SO}_{4}$ aqueous solution were shown in Fig. 12. It can be seen that the erosion corrosion resistance of low temperature nitride IN 718 alloys can be greatly improved and the $475^{\circ} \mathrm{C} / 4 \mathrm{~h}$ treated sample has the best corrosion resistance. In addition, samples nitrided at $500^{\circ} \mathrm{C} / 16 \mathrm{~h}$ are less corrosion resistant than the non-treated samples.

A typical cross-sectional microstructure of $500^{\circ} \mathrm{C} / 8 \mathrm{~h}$ salt bath nitrided specimens from the SEM is depicted in Fig. 13. The result shows that the nitrided layer has a lot of slip lines, which was ascribed to the nitriding process. Hoeft's results showed that nitriding at $360-420^{\circ} \mathrm{C}$, lattice expan-

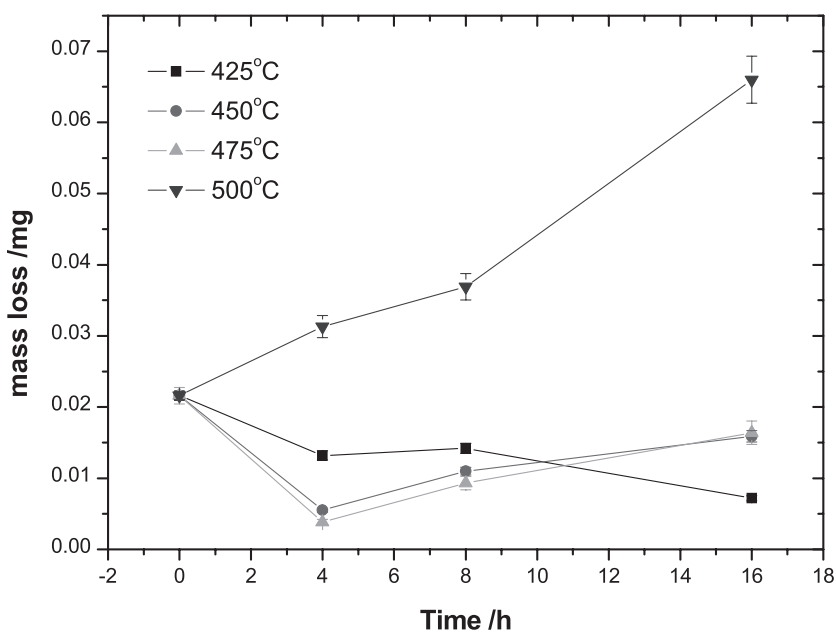

Fig. 12. The effect of nitriding temperature and time on erosion corrosion behavior of nitrided Inconel 718 superalloy.

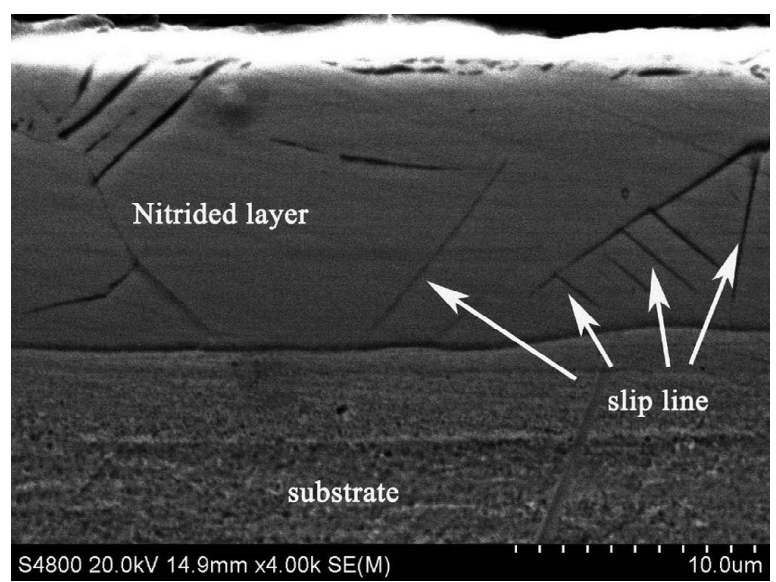

Fig. 13. SEM image of the nitrided Inconel 718 for $8 \mathrm{~h}$ at $500^{\circ} \mathrm{C}$. sion greater than $8 \%$ was achieved with nitrogen concentrations near 40 at.\%. For nitriding temperatures less than $450^{\circ} \mathrm{C}$, high compressive residual stress in the range of $2-3$ $\mathrm{GPa}$ was found and the fracture resistance of these layers was less than $7 \mathrm{MPa} \mathrm{m}^{1 / 2}{ }^{30)}$ It should be noted that there is sufficient evidence to suggest that very high residual stresses are introduced in the nitrided layer produced at low temperature. ${ }^{1)}$ The formation of such slip lines is a structural feature typically in deformed fcc alloys associated with dislocation and stacking fault generation. ${ }^{6}$ It may be due to anisotropy in the diffusion of nitrogen in different crystallographic orientations ${ }^{6)}$ or lattice rotation induced by the anisotropic strain generated during nitriding. ${ }^{9)}$ Such evidence of deformation after nitriding has been reported earlier for IN $690^{9)}$ and IN 718. ${ }^{1)}$ Also, Precipitation of $\mathrm{CrN}$ nanoparticles lead to volume expansion in the nitrided zone. ${ }^{8)}$ With high compressive residual stresses, cracks and nitrides in the nitride layer, the $500^{\circ} \mathrm{C} / 16 \mathrm{~h}$ nitrided IN 718 alloy corroded very fast in our corrosion solutions. And the nitrided layer would be delaminated and seriously eroded. Awe found that the nitrided layer of IN 718 was prone to delamination under contact motion, resulting in a higher overall wear rate. ${ }^{3)}$ So the mass loss rate of the $500^{\circ} \mathrm{C} / 16$ h treated IN 718 alloy exceeded the non-treated sample.

The results of the experiment revealed that low temperature salt bath nitriding can increase the corrosion resistance of IN 718 alloy. A high hardness and corrosion resistance nitrided layer was formed at the surface of the superalloy to protect the damage of the slurry corrosion. ${ }^{31)}$ After treatment at $475^{\circ} \mathrm{C} / 4 \mathrm{~h}$, the nitrided layer of the IN 718 superalloy was mainly composed by the expanded austenite, which has better corrosion resistance and high microhardness. Our results indicated that the $4 \mathrm{~h}$ treated sample has the best corrosion behavior. After nitriding at $475^{\circ} \mathrm{C} / 16 \mathrm{~h}$ or at $500^{\circ} \mathrm{C}$, the expanded austenite decomposed into brittle nitride in the nitrided layer. Dong's results demonstrated that once $\mathrm{CrN}$ has precipitated from the S-phase layer, the corrosion resistance is severely compromised. ${ }^{6}$ Moreover, after high temperature or long term nitriding, the thickness of the nitrided layer increased. Under very high compressive residual stresses, the nitrided layer cracked. This can be especially observed in high temperature and long term nitriding samples. The decomposed and cracked nitrided layer will significantly degrade the corrosion resistance of IN 718 alloy. Therefore, the optimum temperature for obtaining the best corrosion resistance of IN 718 is $475^{\circ} \mathrm{C}$, which is higher than the nitrding temperature of stainless steel. ${ }^{25}$ ) The reason is that the superalloy austenite has more nickel content, making the austenite more stable than that of the austenite stainless steel (316L).

\section{Conclusion}

Based on above investigations, it can be concluded that when IN 718 superalloy is subjected to the salt bath nitriding at $425-500^{\circ} \mathrm{C}$, the following features were observed:

(1) An expanded austenite layer was formed on the surface of substrate when nitriding IN 718 alloy at temperature ranges of $425-475^{\circ} \mathrm{C}$. The thickness of the nitrided layer increased with treating time at temperature ranges of 425 $500^{\circ} \mathrm{C}$. The growth of the nitride layer takes place mainly 
by nitrogen diffusion according to the expected parabolic rate law. The activation energy was calculated as $\sim 166.9$ $\mathrm{kJ} / \mathrm{mol}(1.73 \mathrm{eV})$. The phases shown in the nitrided layers of IN 718 superalloy depend on nitriding parameters (time and temperature) and nitrogen potential.

(2) The salt bath nitriding can effectively improve the surface hardness of IN 718 alloy. The maximum values of hardness measured from the treated surface are observed to be around $2100 \mathrm{HV}_{0.05}$ for $500^{\circ} \mathrm{C} / 16 \mathrm{~h}$, which is about 5 times as hard as the non-treated material $\left(420 \mathrm{HV}_{0.05}\right)$.

(3) Proper low temperature nitriding can improve the erosion corrosion resistance of IN 718 superalloy. Our results suggest that after nitriding at $475^{\circ} \mathrm{C}$ for $4 \mathrm{~h}$, the IN 718 alloy has the best corrosion resistance in comparison to nitriding performed in other temperature or time.

\section{Acknowledgements}

The authors are very grateful to the grant of National Natural Science Foundation of China (Grant No. 51471112) for the financial support of this research. And the author (J.W) would like to thank Richard Lartey and Zhen Li of Case Western Reserve University, USA, for his valuable discussion during the course of the research and writing.

\section{REFERENCES}

1) V. Singh and E. I. Meletis: Surf. Coat. Technol., 201 (2006), 1093.

2) T. Borowski, A. Brojanowska, M. Kost, H. Garbacz and T. Wierzchoń: Vacuum, 83 (2009), 1489.

3) P. K. Aw, A. W. Batchelor and N. L. Loh: Surf. Coat. Technol., 89 (1997), 70.

4) K. T. Rie: Surf. Coat. Technol., 112 (1999), 56.

5) R. Sharghi-Moshtaghin, H. Kahn, Y. Ge, X. Gu, F. J. Martin, P. M. Natishan, R. J. Rayne, G. M. Michal, F. Ernst and A. H. Heuer: Metall. Mater. Trans. A, 41 (2010), 2022.

6) H. Dong: Int. Mater. Rev., 55 (2010), 65
7) S. Zheng, Y. Sun, A. Bloyce and T. Bell: Mater. Manuf. Process., 10 (1995), 815.

8) C. Sudha, R. Anand, V. Thomas Paul, S. Saroja and M. Vijayalakshmi: Surf. Coat. Technol., 226 (2013), 92.

9) T. Czerwiec, H. He, A. Saker, L. Tran Huu, C. Dong, C. Frantz and H. Michel: Surf. Coat. Technol., 174-175 (2003), 131.

10) L. H. Chiu, Y. Y. Su, F. S. Chen and H. Chang: Mater. Manuf. Process., 25 (2010), 316.

11) D. Wang, C.-W. Chen, J. C. Dalton, F. Yang, R. Sharghi-Moshtaghin, H. Kahn, F. Ernst, R. E. A. Williams, D. W. McComb and A. H. Heuer: Acta Mater., 86 (2015), 193.

12) K. M. Eliasen, T. L. Christiansen and M. A. J. Somers: Surf. Eng., 26 (2010), 248.

13) C. Leroy, T. Czerwiec, C. Gabet, T. Belmonte and H. Michel: Surf. Coat. Technol., 142-144 (2001), 241.

14) Y. Sun: J. Alloys Compd., 351 (2003), 241.

15) J. P. Rivièrea, P. Méheusta, J. A. Garcíab, R. Martínezb, R. Sánchezb and R. Rodríguez: Surf. Coat. Technol., 158-159 (2002), 295.

16) K. L. Dahm, K. T. Short and G. A. Collins: Wear, 263 (2007), 625.

17) E. I. Meletis: Surf. Coat. Technol., 149 (2002), 95.

18) P. K. Aw, A. W. Batchelor and N. L. Loh: Wear, 208 (1997), 226.

19) K. Marusic, H. Otmacic, D. Landek and F. Cajner: Surf. Coat. Technol., 201 (2006), 3415.

20) C. F. Yeung, K. H. Lau, H. Y. Li and D. F. Luo: J. Mater. Process. Technol., 66 (1997), 249.

21) G. Li, J. Wang, Q. Peng, C. Li, Y. Wang and B. Shen: J. Mater. Process. Technol., 207 (2008), 187.

22) J. W. Zhang, L. T. Lu, K. Shiozawa, W. N. Zhou and W. H. Zhang: Int. J. Fatigue, 33 (2011), 880.

23) K. Funatani: Met. Sci. Heat Treat., 46 (2004), 277.

24) J. Wang, Y. Lin, D. Zeng, J. Yan and H. Fan: Metall. Mater. Trans. $B, 44$ (2013), 414.

25) J. Wang, Y. Lin, Q. Zhang, J. Yan, D. Zen, R. Huang and H. Fan: Surf. Coat. Technol., 206 (2012), 3399.

26) J. Wang, J. Xiong and T. Zhang: China Patent, No. ZL2011 10184878.1.

27) J. Wang, Y. Lin, M. Li, H. Fan, D. Zeng and J. Xiong: Metall. Mater. Trans. B, 44 (2013), 1010.

$28)$ C. N. J. Wagner, J. P. Boisseau and E. N. Aqua: Trans. Met. Soc. AIME, 223 (1965), 1280

29) K. Salmutter and F. Stranger: Z. Metallkd., 51 (1960), 544.

30) D. Hoeft, B. A. Latella and K. T. Short: J. Phys.: Condens. Matter., 17 (2005), 3547.

31) K. C. Chen, J. L. He, W. H. Huang and T. T. Yeh: Wear, 252 (2002), 580 . 